\title{
Anti-Aggregation Function of Blood Vessels in Piglets of Dairy and Plant Nutrition
}

\section{Elena S. Tkacheva ${ }^{1}$ and Ilya N. Medvedev²}

${ }^{1}$ Vologda State Dairy Farming Academy named after N.V. Vereshchagin, Vologda, Russia

${ }^{2}$ Russian State Social University, Moscow, Russian

ORCID:

Ilya N. Medvedev: http://orcid.org/0000-0002-9263-2720

Elena S. Tkacheva: http://orcid.org/0000-0003-3651-5359

\section{Abstract}

Modern pig farming is a significant sector of modern agriculture in many countries. The attractiveness of its products is associated with their excellent taste and economic affordability. The intensive development of pig breeding considers the latest achievements in the field of pig biology during their early ontogenesis. Optimal functioning of hemostasis in growing piglets relies on platelet activity. Its low severity during the phase of milk and vegetable nutrition provides them with the optimal

Corresponding Author:

Ilya N. Medvedev

ilmedv1@yandex.ru

Published: 5 April 2021

Publishing services provided by Knowledge E

(c) Elena S. Tkacheva1 and Ilya N. Medvedev2. This article is distributed under the terms of the Creative Commons

Attribution License, which permits unrestricted use and redistribution provided that the original author and source are credited.

Selection and Peer-review under the responsibility of the DonAgro Conference Committee.

\section{G OPEN ACCESS} functional state of primary hemostasis, the success of microcirculation in the internal organs, and sufficient activity of all functional and biochemical processes. In the blood of healthy piglets during the phase of dairy and plant nutrition, a decrease in the number of peroxidation products was noted due to an increase in the level of antioxidant protection of their plasma. This minimized their platelet and vascular wall alteration and provided optimal platelet-vascular interactions. This study shows that the gradual increase in the platelet aggregation that develops in piglets at this age is functionally balanced by the increase in the disaggregation properties of blood vessels and creates conditions for optimal blood flow in small-caliber vessels.

Keywords: piglets, phase of dairy and plant nutrition, platelets, aggregation, disaggregation, early ontogenesis.

\section{Introduction}

Pig farming is one of the most important branches of modern agriculture in many countries [1]. Its high profitability is determined by the high growth rate of pigs and multiple pregnancy of breeding sows. In this regard, pig farming in many regions of the globe is an important source of protein food. The continuing population growth places a challenge before pig farming, as it requires a significant increase in the volume of production of food products of pig breeding. There is no doubt that to solve this problem it is necessary to obtain new physiological knowledge about the body of the 
pig during its ontogeny and its rapid practical application. It is particularly important to clarify the age dynamics of pigs hematological parameters, especially those related to the hemostatic system [2].

Functionally essential components of the hemostatic system of pigs are platelets and blood vessels. Their activity determines the status of primary hemostasis and microcirculation in the organism of pigs of any age $[3,4]$. An aggregation and disaggregation of platelets are very important for the formation of aggregates in the lumen of small blood vessels throughout the early ontogeny and, consequently, for the formation of economically important characteristics in pigs [5]. However, despite the importance of the trophic balance between platelet and vascular components of primary hemostasis, pigs' features during the phase of milk-vegetable food remain poorly understood. In this regard, the goal was to establish the dynamics of the activity of the aggregation of platelets and antiaggregatory activity of the vessels in piglets during the phase of milk-vegetable diet.

\section{Materials and Methods}

This study was carried out in strict accordance with the ethical principles established by the European Convention for the Protection of Vertebrates Used for Scientific Purposes (adopted in Strasbourg on March 18, 1986 and confirmed in Strasbourg on June 15, 2006).

The work was performed on 36 healthy pigs of dairy nutrition, purebred breed of large white species. All the animals were examined on the 21st day, 25th day, 30th day, 35th day and 40th day of their life.

All piglets were evaluated for plasma lipid peroxidation activity by the level of acyl hydroperoxides and thiobarbituric acid-active products in it, using a kit manufactured by Agat-Med (Russia) taking into account the level of plasma antioxidant activity [6].

Platelet aggregation activity was evaluated [7] using a visual micromethod with adenosine diphosphate $\left(0.5 \times 10^{-4} \mathrm{M}\right)$, collagen (1: 2 dilution of the main suspension), thrombin $(0.125 \mathrm{U} / \mathrm{ml})$, ristomycin $(0.8 \mathrm{mg} / \mathrm{ml})$ and adrenaline $\left(5.0 \times 10^{-6} \mathrm{M}\right)$ in plasma, which was standardized by the number of platelets contained in it to $200 \times 10^{9}$ platelets/l. The authors counted the piglets' index of anti-aggregation activity of the vascular wall when dividing the time of the platelet aggregation in plasma taken after an episode of venous stasis by the time of development of the platelet aggregation in plasma taken without it [7]. 
The intravascular platelet aggregation was evaluated by phase contrast microscopy [8]. The results of the work performed were processed using Student's criterion (td).

\section{Results}

In the blood of piglets during the phase of dairy and plant nutrition, there was a decrease in the level of primary lipid peroxidation products: acyl hydroperoxides - from 1.38 \pm 0.019 $\mathrm{D}_{233} / 1 \mathrm{ml}$ to $1.22 \pm 0.011 \mathrm{D}_{233} / 1 \mathrm{ml}$ and its secondary products, thiobarbituric acid-active compounds - from 3.21 $\pm 0.018 \mu \mathrm{mol} / /$ to $3.01 \pm 0.025 \mu \mathrm{mol} / \mathrm{l}$, respectively. The revealed decrease in peroxidation occurred in piglets due to an increase in their antioxidant plasma defense activity at the age from $35.9 \pm 0.12 \%$ to the level of $39.8 \pm 0.09 \%$. During the phase of dairy and plant nutrition, piglets showed some acceleration of the platelet aggregation. The fastest one was the platelet aggregation caused by collagen (table 1). A little later, the platelet aggregation occurred in response to ADP, ristomycin and $\mathrm{H}_{2} \mathrm{O}_{2}$. The platelet aggregation in response to thrombin and adrenaline occurred in animals even later, also gradually accelerating during observation $(p<0.05)$.

For piglets during the phase of milk and plant nutrition, a tendency to increase the index of anti-aggregation activity of the vascular wall, in relation to all used aggregation stimulants, was characteristic (table 1). The maximum value in them was the index of antiplatelet activity of the vascular wall, calculated in relation to adrenaline, which amounted to $1.57 \pm 0.08$ by the end of the observation. Slightly lower ones were the values of the index of antiaggregatory activity of the vascular wall with respect to $\mathrm{H}_{2} \mathrm{O}_{2}$ and thrombin. Even lower ones in piglets were indicators of antiaggregational activity of the vascular wall in relation to the collagen inducer (increased when observed to $1.51 \pm 0.04$ ), in relation to ADP (increased when observed to $1.50 \pm 0.05$ ) and in relation to ristomycin (increased when observed to $1.54 \pm 0.11$ ).

During the period of the third phase of early ontogenesis in the blood of piglets, the number of small and large platelet aggregates increased by $20.0 \%$ and $31.2 \%$, respectively. The number of platelets in the composition of these aggregates increased to $8.9 \pm 0.04 \%$ against $7.8 \pm 0.08 \%$ at the beginning of the observation (table 1 ).

It becomes clear that for piglets during the phase of milk and vegetable nutrition, simultaneous increase in the platelet aggregation and the disaggregation properties of blood vessels is characteristic, which should be regarded as an important mechanism for the implementation of homeostasis processes at this stage of ontogenesis. 


\section{Discussion}

In piglets, the phase of dairy and plant nutrition is considered as one of the most important stages of early ontogenesis. During this period, the adaptation of the animal's organism to environmental conditions intensifies and adaptation to the consumption of plant feed occurs [9]. During the phase of dairy and plant nutrition, there is a continuation of the development of organs and systems according to the plan determined by the genetic program of the body, taking into account the existing environmental conditions $[10,11]$. This process proceeds in conditions of complete self-regulation by systems integrating the body, including the hemostatic system. It is biologically significant, as it indirectly regulates the level of functioning of internal organs due to control over the state of the aggregation of blood $[12,13]$.

The weakness of lipid peroxidation inherent in the examined piglets ensures a low degree of damage to platelet structures during the dairy and plant nutrition phase, which ensures weak synthesis of proaggregants in them. This situation intensifies microcirculation in tissues, which is necessary for the successful functioning of the body in conditions of the beginning of consumption of plant feed [14].

A slight increase in platelet adhesion in piglets during the third phase of early ontogenesis, due to an increase in the ability to bind to collagen and ristomycin, was fully balanced by the anti-adhesive properties of the vessels. Strengthening of vascular control over adhesion was confirmed by an increase in the index of anti-aggregation activity of the vascular wall in relation to collagen and ristomycin. The increase in adhesion itself was indirectly confirmed by the accelerated platelet aggregation with these inducers [15]. The activation of platelet adhesion in piglets was apparently based on an increase in the number of glycoproteins la-lla and VI on their membranes and increased generation of von Willebrand factor in the vessel walls. This was supplemented by an intensification of its binding with an increased number of platelet glycoproteins lb, which are receptors for von Willebrand factor $[16,17]$. Undoubtedly, the activation of vascular control over platelet adhesion is associated with increased synthesis of prostacyclin and nitric oxide in the vessels of piglets during the phase of milk-vegetable nutrition.

Due to the increase in the synthesis of antiplatelet agents in the walls of blood vessels in piglets, the effect on the platelets of strong aggregation stimulators - collagen and thrombin - remained at the physiological level. This ensured their optimal activity of phospholipase $\mathrm{C}$, components of the phosphoinositol activation pathway of platelets and enzymes that phosphorylate proteins of the platelet contractile system [18, 19]. 
TABLE 1: Indicators of primary hemostasis in piglets of dairy and plant nutrition

\begin{tabular}{|c|c|c|c|c|c|}
\hline \multirow[t]{2}{*}{ Registered parameters } & \multicolumn{5}{|c|}{ Age of piglets, $n=36, M \pm m$} \\
\hline & 21st day & 25th day & 30th day & 35th day & 40th day \\
\hline $\begin{array}{l}\text { Platelet aggregation } \\
\text { with ADP, s }\end{array}$ & $40.2 \pm 0.14$ & $38.5 \pm 0.12$ & $36.1 \pm 0.10$ & $\begin{array}{l}35.2 \pm 0.09 \\
P<0.05\end{array}$ & $33.8 \pm 0.07$ \\
\hline $\begin{array}{l}\text { Vascular wall } \\
\text { anti-aggregation index } \\
\text { with ADP }\end{array}$ & $1.47 \pm 0.08$ & $1.47 \pm 0.06$ & $1.48 \pm 0.04$ & $1.49 \pm 0.06$ & $1.50 \pm 0.05$ \\
\hline $\begin{array}{l}\text { Platelet aggregation } \\
\text { with collagen, } s\end{array}$ & $30.0 \pm 0.05$ & $29.0 \pm 0.10$ & $27.4 \pm 0.12$ & $\begin{array}{l}25.7 \pm 0.09 \\
P<0.05\end{array}$ & $23.8 \pm 0.09$ \\
\hline $\begin{array}{l}\text { Collagen vascular wall } \\
\text { anti-aggregation index }\end{array}$ & $1.46 \pm 0.08$ & $1.47 \pm 0.06$ & $1.48 \pm 0.05$ & $1.49 \pm 0.03$ & $1.51 \pm 0.04$ \\
\hline $\begin{array}{l}\text { Platelet aggregation } \\
\text { with thrombin, } \mathrm{s}\end{array}$ & $55.2 \pm 0.09$ & $53.1 \pm 0.12$ & $52.0 \pm 0.07$ & $\begin{array}{l}50.6 \pm 0.08 \\
p<0.05\end{array}$ & $48.2 \pm 0.08$ \\
\hline $\begin{array}{l}\text { Vascular wall } \\
\text { antiaggregation index } \\
\text { with thrombin }\end{array}$ & $1.49 \pm 0.04$ & $1.50 \pm 0.09$ & $1.51 \pm 0.10$ & $1.52 \pm 0.06$ & $1.54 \pm 0.09$ \\
\hline $\begin{array}{l}\text { Platelet aggregation } \\
\text { with ristomycin, } \mathrm{s}\end{array}$ & $42.8 \pm 0.12$ & $40.5 \pm 0.08$ & $38.3 \pm 0.15$ & $\begin{array}{l}36.5 \pm 0.11 \\
p<0.05\end{array}$ & $34.7 \pm 0.05$ \\
\hline $\begin{array}{l}\text { Vascular wall } \\
\text { antiaggregation index } \\
\text { with ristomycin }\end{array}$ & $1.48 \pm 0.04$ & $1.49 \pm 0.07$ & $1.50 \pm 0.06$ & $1.52 \pm 0.09$ & $1.54 \pm 0.11$ \\
\hline $\begin{array}{l}\text { Platelet aggregation } \\
\text { with } \mathrm{H}_{2} \mathrm{O}_{2}, \mathrm{~s}\end{array}$ & $44.5 \pm 0.10$ & $42.7 \pm 0.13$ & $40.5 \pm 0.12$ & $\begin{array}{c}38.4 \pm 0.07 \\
P<0.05\end{array}$ & $36.8 \pm 0.16$ \\
\hline $\begin{array}{l}\text { Index of } \\
\text { antiaggregatory activity } \\
\text { of the vascular wall } \\
\text { with } \mathrm{H}_{2} \mathrm{O}_{2}\end{array}$ & $1.49 \pm 0.06$ & $1.50 \pm 0.05$ & $1.51 \pm 0.04$ & $1.53 \pm 0.09$ & $1.54 \pm 0.06$ \\
\hline $\begin{array}{l}\text { Platelet aggregation } \\
\text { with adrenaline, } s\end{array}$ & $95.8 \pm 0.16$ & $93.1 \pm 0.20$ & $90.4 \pm 0.14$ & $\begin{array}{l}87.5 \pm 0.19 \\
p<0.05\end{array}$ & $84.5 \pm 0.15$ \\
\hline $\begin{array}{l}\text { Adrenaline vascular } \\
\text { wall anti-aggregation } \\
\text { index }\end{array}$ & $1.51 \pm 0.05$ & $1.53 \pm 0.06$ & $1.55 \pm 0.08$ & $1.56 \pm 0.10$ & $1.57 \pm 0.08$ \\
\hline $\begin{array}{l}\text { The number of platelets } \\
\text { in the aggregates, } \%\end{array}$ & $7.8 \pm 0.08$ & $8.2 \pm 0.11$ & $8.4 \pm 0.09$ & $\begin{array}{l}8.6 \pm 0.07 \\
p<0.05\end{array}$ & $8.9 \pm 0.04$ \\
\hline $\begin{array}{l}\text { The number of small } \\
\text { aggregates of } 2-3 \\
\text { platelets per } 100 \\
\text { free-lying platelets }\end{array}$ & $3.5 \pm 0.08$ & $3.7 \pm 0.04$ & $\begin{array}{l}3.9 \pm 0.09 \\
p<0.05\end{array}$ & $\begin{array}{c}4.0 \pm 0.07 \\
p<0.01\end{array}$ & $4.3 \pm 0.08$ \\
\hline $\begin{array}{l}\text { The number of medium } \\
\text { and large aggregates, } 4 \\
\text { or more platelets per } \\
100 \text { free-lying platelets }\end{array}$ & $0.20 \pm 0.06$ & $0.22 \pm 0.08$ & $\begin{array}{l}0.23 \pm 0.04 \\
P<0.05\end{array}$ & $\begin{array}{l}0.25 \pm 0.10 \\
P<0.01\end{array}$ & $0.27 \pm 0.05$ \\
\hline
\end{tabular}

Legend: $p$ - the reliability of the age dynamics of indicators.

A gradual increase in the synthesis of prostacyclin and nitric oxide in the vessel walls during the phase of milk and plant nutrition in piglets retains a physiologically optimal level of influence on platelet receptors of weak aggregation inducers, adenosine diphosphate and adrenaline, as well [20, 21]. The achieved effect, apparently, is associated with an increase in the number and increase in the activity of platelet receptors not only 
to aggregation inducers and fibrinogen (GPIIB-IIIa), but also to vascular disaggregants [22].

An increase in the disaggregation effects from the vessels is associated with the process of weakening of the functional properties of phospholipase $A 2$ in platelets of piglets, which led to activation of the release of a sufficient amount of arachidonic acid from their phospholipids [23]. It may be thought that an increase in the blood concentration of piglets during the phase of milk and vegetable nutrition of the concentration of disaggregants seriously inhibits their platelet cyclooxygenase and thromboxane synthetase activity and weakens the synthesis of proaggregate prostaglandins in platelets [24]. The increase in the platelet aggregation detected in piglets during the third phase of early ontogenesis in vitro was consistent with the data obtained by evaluating the intravascular activity of platelets $[25,26]$. The increase in the index of antiplatelet activity of the vascular wall found in piglets indicated a functional balance of the activity of proaggregate and disaggregant influences in the blood [27]. Also, the results indicated a low degree of collagen contact of the subendothelium of piglets at this age and their blood due to the high safety of the endothelial lining of the vessels $[28,29]$.

\section{Conclusion}

The balance of hemostatic activity of platelets and blood vessels in piglets is very significant for the functioning of the entire hemostasis system. Their sufficiency in piglets ensures the optimum fluid properties of the blood and the success of microcirculation in their organs. The platelet aggregation and adequate control of it from the vessels during the entire phase of dairy and plant nutrition very much determine the intensity of the anabolic processes in the body of piglets, and therefore the formation of their productive qualities. Piglets during the phase of dairy and plant nutrition are characterized by low plasma lipid peroxidation activity. It can be assumed that this greatly contributes to their increased antiaggregatory activity of their vessels and creates the conditions for an adequate level of vascular control over the hemostatic properties of platelets. The increase in platelet activity occurring in piglets during the third phase of early ontogenesis is fully balanced by the antiaggregatory manifestations of blood vessels. This balance can be considered as the basis for maintaining the optimum hemocirculation in the capillaries of piglets of this age and ensuring high activity of metabolic processes in the tissues, and, consequently, the maximum possible severity of growths. 


\section{Funding}

The study was conducted entirely at the expense of the authors.

\section{Acknowledgement}

The authors would like to thank their colleague for their contribution and support to the research. They are also thankful to all the reviewers who gave their valuable inputs to the manuscript and helped in completing the paper.

\section{Conflict of Interest}

The authors have no conflict of interest to declare.

\section{References}

[1] Maksimov, V. I., et al. (2018). Physiological Dynamics of Microrheological Characteristics of Erythrocytes in Piglets during the Phase of Milk Nutrition. Research Journal of Pharmaceutical, Biological and Chemical Sciences, vol. 9, issue 5, pp. 454-459.

[2] Tkacheva, E. S. and Zavalishina, S. Y. (2018). Physiology of Platelet Hemostasis in Piglets during the Phase of Newborns. Research Journal of Pharmaceutical, Biological and Chemical Sciences, vol. 9, issue 5, pp. 1912-1918.

[3] Zavalishina, S. Y. (2018). Functional Properties of Coagulation Hemostasis in Calves During the Phase of Dairy-Vegetative Nutrition. Research Journal of Pharmaceutical, Biological and Chemical Sciences, vol. 9, issue 5, pp. 784-790.

[4] Karpov, V.Yu., et al. (2020). The Potential of Health Tourism Regarding Stimulation of Functional Capabilities of the Cardiovascular System. Bioscience Biotechnology Research Communications, vol. 13, issue 1, pp. 156-159.

[5] Zavalishina, S.Yu. (2020). Functional Activity of the Cardiorespiratory System and the General Level of Physical Capabilities Against the Background of Regular Physical Exertion. Bioscience Biotechnology Research Communications, vol. 13, issue 4, pp. 2327-2331.

[6] Barkagan, Z. S. and Momot, A. P. (2008). Diagnosis and Controlled Therapy of Hemostatic Disorders. Moscow: NEWYAMED, p. 292. 
[7] Shitikova, A. S. (2000). Platelet Hemostasis. St. Petersburg: St. Petersburg State Medical University, p. 227.

[8] Shitikova, A. S. (2008). Thrombocytopathy is Congenital and Acquired. St. Petersburg: Information and Publishing Center of the Military Medical Academy, p. 384.

[9] Zavalishina, S. Y. (2018). Functioning of Mechanisms of Hemocoagulation Restriction in Calves at Change of Methods of Nutrition. Research Journal of Pharmaceutical, Biological and Chemical Sciences, vol. 9, issue 5, pp. 800-806.

[10] Zavalishina, S. Y. (2018). Functioning of Platelets in Milk and Vegetable Nutrition Calves. Research Journal of Pharmaceutical, Biological and Chemical Sciences, vol. 9, issue 5, pp. 943-949.

[11] Makhov, A. S. (2018). Perspectives of Rink-Bendi Development among People with Hearing Impairment in Russia. Research Journal of Pharmaceutical, Biological and Chemical Sciences, vol. 9, issue 5, pp. 139-146.

[12] Tkacheva, E.S., Zavalishina, S.Yu. (2018). Physiological Aspects Of Platelet Aggregation In Piglets Of Milk Nutrition. Research Journal of Pharmaceutical, Biological and Chemical Sciences, vol. 9, issue 5, pp. 74-80.

[13] Zavalishina, S. Y. (2018). Functional Activity of Plasma Hemostasis in Neonatal Calves with Iron Deficiency, Who Received Ferroglucin and Glycopin. Research Journal of Pharmaceutical, Biological and Chemical Sciences, vol. 9, issue 5, pp. 1186-1191.

[14] Zavalishina, S. Y. (2018). Functional Properties of Anticoagulation and Fibrinolysis in Calves of Plant Nutrition. Research Journal of Pharmaceutical, Biological and Chemical Sciences, vol. 9, issue 5, pp. 1082-1087.

[15] Vorobyeva, N.V., et al. (2018). Influence Of Physical Exercise On The Activity Of Brain Processes. Research Journal of Pharmaceutical, Biological and Chemical Sciences, vol. 9, issue 6, pp. 240-244.

[16] Zavalishina, S. Y. (2018). Physiology of Vascular Hemostasis in Newborn Calves. Research Journal of Pharmaceutical, Biological and Chemical Sciences, vol. 9, issue 5, pp. 1037-1044.

[17] Kulikov, E.V., et al. (2020). The effects of meldonium on microrheological abnormalities of erythrocytes in rats with obesity: An experimental study. Bali Medical Journal, vol. 9, issue 2, pp. 444-450.

[18] Zavalishina, S.Yu. (2020). Functional Features of Hemostasis in Weakened Newborn Calves Treated with Aminosol. Bioscience Biotechnology Research Communications, vol. 13, issue 3, pp. 1251-1256. 
[19] Zavalishina, S. Y. (2018). Functional Properties of Hemocoagulation in Calves of Dairy Nutrition. Research Journal of Pharmaceutical, Biological and Chemical Sciences, vol. 9, issue 5, pp. 1016-1022.

[20] Makhov, A. S. (2018). The Basic Needs of Hearing Impaired People in Organizing Football Training. Research Journal of Pharmaceutical, Biological and Chemical Sciences, vol. 9, issue 5, pp. 121-126.

[21] Zavalishina, S. Y. (2018). Deficiency of Iron as a Cause of Dysfunction in Calves and Piglets. Research Journal of Pharmaceutical, Biological and Chemical Sciences, vol. 9, issue 5, pp. 978-983.

[22] Usha, B.V. et al. (2019). Diagnostics of early dysfunctions of anticoagulant and fbrinolytic features of rats' vessels in the course of metabolic syndrome formation with the help of fructose model. Bali Medical Journal, vol. 8, issue 1, pp. 201-205.

[23] Zavalishina, S. Y. (2018). Functional Antiaggregatory Properties of Blood Vessels in Calves during Transition from Dairy to Plant Type of Nutrition. Research Journal of Pharmaceutical, Biological and Chemical Sciences, vol. 9, issue 5, pp. 1110-1116.

[24] Zavalishina, S. Y. (2018). Physiological Features of Vascular Hemostasis in Calves of Dairy-Vegetative Food. Research Journal of Pharmaceutical, Biological and Chemical Sciences, vol. 9, issue 5, pp. 1137-1143.

[25] Zavalishina, S.Yu. (2018). Functional Features Of Vascular Hemostasis In Calves Of Dairy Nutrition. Research Journal of Pharmaceutical, Biological and Chemical Sciences, vol. 9, issue 6, pp. 1754-1759.

[26] Zavalishina, S. Y. (2018). Functional Features of Platelets in Newborn Calves with Iron Deficiency. Research Journal of Pharmaceutical, Biological and Chemical Sciences, vol. 9, issue 5, pp. 1153-1158.

[27] Makurina, O.N., et al. (2020). The Ability to Correct a Persons Posture with Regular Exercise. Bioscience Biotechnology Research Communications, vol.13, issue 3, pp. 1088-1093.

[28] Fayzullina, I.I., et al. (2020). Improving the Level of Socio-Psychological Adaptation in First-Year Students of a Russian University Moscow, Russia. Bioscience Biotechnology Research Communications, vol.13, issue 3, pp.1231-1235.

[29] Vorobyeva, N.V., et al. (2018). Endothelial Functions in People with High Normal Blood Pressure Experiencing Regular Exercise. Bioscience Biotechnology Research Communications, vol.13, issue 2, pp. 451-455. 